\title{
DAKWAH CYBERMEDIA
}

\section{Oleh: \\ Bustanul Arifin*}

\section{Abstrak}

Artikel ini berusaha membahas tentang dakwah melalui cyber media, yang dalam konteks dakwah, multimedia yang digunakan tidak sekadar memfungsikan sebahagian fungsi komunikasi seperti menginformasikan, mendidik dan mempengaruhi saja, tetapi juga mengoptimalisasikan upaya mengajak atau menyeru (to invitel to propagate). Sehingga multi media atau dalam konsepsi ilmu dakwah disebut wasilah, mengadopsi segala produk media komunikasi terutama multimedia berbasis teknologi informasi dan komunuikasi dapat digunakan sebagai media dakwah.

Internet menjadi salah satu media paling efektif untuk menyalurkan bakat atau gagasan. Hal ini disebabkan oleh jangkauan internet yang dapat diakses secara global oleh seluruh manusia di seluruh penjuru dunia. Oleh karena itu, dakwah melalui multimedia berbasis teknologi informasi dan komunikasi menjadi kebutuhan mutlak yang tidak bisa ditawar lagi. Sudah saatnya para pegiat dakwah mengejar ketertinggalannya dalam konteks pemanfaatan teknologi informasi dan komunikasi untuk berdakwah dengan standar minimal menjadi pengguna (user).

Kata Kunci: Cybermedia, Dakwah

\section{Pendahuluan}

Teknologi di era globalisasi telah mengalami kemajuan yang begitu pesat, beragam macam media komunikasi bersaing dalam memberikan informasi yang tanpa batas. Dunia kini telah

\footnotetext{
${ }^{*}$ IAIT Kediri
}

Volume 26 Nomor 1 Januari 2015 
dan sedang berubah, bergulir dalam proses revolusi informasi dan komunikasi yang melahirkan peradaban baru sehingga mempermudah manusia untuk saling berhubungan serta meningkatkan mobilitas sosial. Kehadiran media massa, seperti surat kabar, radio, televisi dan internet, sebagai komunikasi abad modern telah berpengaruh luas. Suatu pesan atau berita dapat dengan mudah diterima oleh masyarakat dalam waktu yang relatif singkat.

Fasilitas internet merupakan yang terlengkap dan terefisien, dimana segala bentuk dan macam informasi dapat diakses dengan mudah dan murah. Kemudian di idukung dengan semakin menjamurnya warung internet yang memasang tarif murah. Kemana, di manapun dan dengan siapapun kita berkomunikasi dapat kita lakukan dengan mengunakan fasilitas internet. fasilitas tersebut biasa dikenal dengan istilah mailing list, yaitu komunikasi yang dilakukan melalui tulisan yang bersifat langsung.

Di samping itu, hingga saat ini aktivitas dakwah di kalangan umat muslim masih tetap berlangsung dan perhatian pada dakwah semakin besar. Dakwah tidak lagi dilakukan sebatas pemberian khutbah di masjid/mushalla, kantor-kantor, sekolah dan lembaga formal lainnya. Seiring dengan meningkatnya kemajuan teknologi informasi, penyebaran dakwah Islamiyah tersebar melalui media teknologi, khususnya teknologi informasi seperti Internet. Dengan trend digital life, sesungguhnya kemudahan dari Allah SWT untuk nasyrul fikrah semakin terbuka lebar.

Jika kita menginginkan kegiatan dakwah berjalan secara efektif dan efisien maka harus menggunakan cara-cara yang strategis dan tepat dalam menyampaikan pesan-pesan dakwah. Salah satu aspek yang bisa ditinjau adalah dari segi sarana dan prasarana dalam hal ini adalah media dakwah. Dakwah 
merupakan kegiatan yang bersifat universal yang menjangkau semua segi kehidupan manusia.

Seiring dengan kemajuan teknologi, cara berdakwah sekarang juga mengalami mengalami perkembangan. Dakwah tidak lagi dilakukan secara sederhana dan bertatap muka secara langsung, tetapi mulai memanfaatkan kemajuan teknologi media komunikasi. Media komunikasi terbagi menjadi dua yaitu, cetak atau dan elektronik. Pemanfaatan kedua media itu tentunya dilakukan agar pesan-pesan dakwah dapat diterima oleh lebih banyak orang dimanapun berada. Dengan demikian, dakwah melalui media memiliki dampak yang luas terhadap keberhasilan dakwah.

Dakwah melalui internet merupakan inovasi terbaru dalam syiar Islam dan memudahkan para da'i dalam melebarkan sayap-sayap dakwahnya. Penggunaan media internet sebagai media dakwah merupakan kesempatan dan tantangan untuk mengembangkan dan memperluas cakrawala dakwah Islamiyah. Kesempatan yang dimaksud ialah bagaimana orang-orang yang peduli terhadap kemampuan dakwah maupun memanfaatkan media internet tersebut sebagai sarana dan media dakwah untuk menunjang proses dakwah Islamiyah. Umat Muslim harus mampu menguasai dan memanfaatkan dengan sebaik-baiknya perkembangan teknologi informasi. Singkatnya kemudahan yang ditawarkan internet sangat potensial dimanfaatkan untuk media dakwah.

\section{Pembahasan}

\section{Pengertian Cybermedia (Sosial Network)}

Cybermedia adalah salah satu penyaluran pesan lewat media massa yang distribusinya melalui internet, dimana cara penyajiannya bersifat luas, up to date (terkini), interaktif dan bersifat dua arah. Simpelnya, cybermedia di sini lebih bermakna sebagai jurnalisme online. Keberadaan Cybermedia memang 
menjadi angin segar bagi kalangan jurnalis cetak. Hampir seluruh pers cetak di Indonesia mempunyai situs onlinenya misal detik.com, kompas.com, kr.co.id dan masih bayak lagi. Sedangkan dalam arti luas cybermedia mencakup segala komunikasi dan interaksi yang menggunkan media internet. Misal : Friendster, Facebook, Youtube, blog, msn live, skype dan lain-lain.

Sementara jejaring sosial (sosial network) merupakan situs dimana setiap orang bisa membuat web page pribadi, kemudian terhubung dengan teman-teman untuk berbagi informasi dan berkomunikasi. Jejaring sosial terbesar antara lain Facebook, BBM, Whats App dan Twitter. Jika media tradisional menggunakan media cetak dan media broadcast, maka media sosial menggunakan internet. Media sosial mengajak siapa saja yang tertarik untuk berpertisipasi dengan memberi kontribusi dan feedback secara terbuka, memberi komentar, serta membagi informasi dalam waktu yang cepat dan tak terbatas.

\section{Sejarah Internet}

Internet atau interconnected network adalah sebuah sistem komunikasi global yang menghubungkan komputerkomputer dan jaringan-jaringan komputer di seluruh dunia. ${ }^{1}$ Jaringan internet yang kita kenal saat ini, pertama kali dikembangkan pada tahun 1969 oleh Departemen Pertahanan Amerika Serikat dengan nama ARPANET (Advanced Research Projects Agency). ARPANET dibangun untuk menghindari pemusatan informasi di satu titik dengan pembuatan suatu jaringan komputer yang terbesar. Pemusatan informasi dipandang rawan mengalami penghancuran apabila terjadi peperangan. Lain halnya dengan adanya jaringan. Apabila satun bagian dari jaringan terputus, maka jalur yang melalui

1 Pardianto, Meneguhkan Dakwah Melalui New Media, Jurnal: Komunikasi Islam, ISBN 2088-6314, Volume 03, Nomor 01, Juni 2013. 204

Volume 26 Nomor 1 Januari 2015 
jaringan tersebut dapat secara otomatis dipindahkan ke saluran lain (Iskandar 2009: 1-2).

Pada awalnya, internet hanya menawarkan layanan berbasis teks meliputi remote access, email/messanging, maupun diskusi melalui news- group (Usenet). Terobosan berarti ketika Gedung Putih (White House) mulai online di internet dan pemerintah Amerika Serikat meloloskan National Information Infrastructure Act. Penggunaan internet secara komersial dimulai pada 1994 dipelopori oleh perusahaan Pizza Hut, sedangkan internet banking pertama kali diaplikasikan oleh First Virtual, Compuserve, Amerika Online, Prodigy. Dan akhirnya mulai memberikan layanan akses internet bagi masyarakat umum. $^{2}$

Masyarakat Indonesia pertama kali bisa mengakses layanan internet komersial sekitar tahun 1994. Sebelumnya, beberapa perguruan tinggi seperti Universitas Indonesia telah terlebih dahulu tersambung dengan jaringan internet melalui gateway, yang menghubungkan universitas itu dengan network di luar negeri. Internet sebenarnya mengacu kepada istilah untuk menyebut sebuah jaringan, bukan suatu aplikasi tertentu. Oleh karena itu, internet tidaklah memiliki manfaat apa-apa tanpa ada aplikasi yang sesuai. Internet menyediakan beberapa aplikasi yang dapat digunakan untuk berbagai kebutuhan. Setiap apli- kasi berjalan di atas sebuah protokol tertentu. Protokol, adalah aturan yang mengatur bagaimana sebuah aplikasi berkomunikasi dalam suatu jaringan. Sedangkan software aplikasi yang berjalan di atas sebuah pro- tokol disebut aplikasi client.

Menurut Werner (2005) Internet memberikan perangkat praktis untuk menjadi penerbit tingkat dunia, yang dengan sendirinya merupakan sebuah perkembangan revolusioner. Ia juga memberikan kekuatan, informasi yang sebelumnya tidak tersedia dan melakukan kontrol terhadap

\footnotetext{
${ }^{2}$ Ibid.
} 
pesan-pesan yang terekspos padanya. Menurut La Quey (1997: 1) nilai yang ditawarkan internet dapat dikiaskan sebagai sistem jalan raya berkecepatan tinggi yang memperpendek waktu perjalanan, atau dapat diibaratkan sebuah perpustakaan yang dapat dikunjungi setiap saat, dengan kelengkapan buku, sumber informasi atau kemungkinan penelurusan informasi yang tak terbatas. Atau sebagai sebuah jamuan pesta semalam suntuk dengan penerimaan tamu ramah yang siap menyambut setiap saat, itulah keberadaan internet saat ini.

Pardianto menyatakan bahwa bagian internet yang paling bertanggung jawab dalam aktivitas on-line ialah fraksi jaringan yang disebut world wide web (www). Pada prinsipnya, www merupakan sebuah koleksi besar yang memuat data dalam jumlah banyak melalui beragam media, naskah, gambar, suara, video dan lain-lain. Web bekerja dengan cara menyediakan file dari komponen yang disebut server, file yang ada pada server tersimpan dalam satu sumber, yaitu dengan cara menyediakan sebuah sistem alamat file yang konsistensi atau uniform resource locators (URL), URL adalah kotak alamat pelacak (browser), komputer mendapatkan file yang terdapat dalam URL tersebut dengan menggunakan http (hyper text transfer protocol), penggunaan http memungkinkan untuk meng- akses file yang tersimpan di manapun di dunia ini. File tersebut seolah- olah tersimpan dalam satu komputer induk saja. Kemudahan dalam web di sebabkan hadirnya bahasa universal yakni HTML (hyper text multi language), yang menyusun sebuah file sehingga komputer dapat menata file-file lain, keterbukaan HTML memungkinkan setiap orang menciptakan isi dan kemudian menem-patkannya dalam website, dan hasilnya adalah ledakan data. ${ }^{3}$

Ali Aziz dalam buku "Ilmu Dakwah" mengemukakan bahwa pada saat ini perkembangan internet mulai

${ }^{3}$ Ibid. 
merambah dan menempatkan posisi yang kuat di deretan media massa yang telah ada. ${ }^{4}$ Ketika internet dikenal masyarakat, sudah dapat diramalkan bahwa media ini akan menjadi popular di kemudian hari. Hal itu terlihat saat perangkatperangkat komputer baik hardware maupun software terus berkembang, terus disempurnakan tiap menit di komputer, sejauh ini pula sambutan masyarakat sangat antusias dalam pasaran.

Pemanfaatan internet dewasa ini, telah merasuk pada hampir semua aspek kehidupan, baik sosial, ekonomi, pendidikan, hiburan bahkan keagamaan. Pendeknya, hampir semua hal yang dapat kita pikirkan. Kita dapat mengetahui berita-berita teraktual hanya dengan mengakses situs-situs berita di web. Jadi internet menyajikan informasi lebih cepat bila dibanding dengan media massa apapun.

\section{Landasan Teologis dan Teoritis Dakwah Multimedia}

Dalam pandangnag Islam ada hal yang mendasar yang perlu dicatat bahwa segala bentuk multimedia tersebut tidak mungkin berkembang dan dikembangkan tanpa ada sesuatu yang menjadi modal untuk berkomunikasi itu secara fundamental. Dalam pandangan Islam, sesuatu tidak terjadi menjadi ada dengan sendirinya tetapi di adakan oleh yang maha mengadakan yaitu Alloh SWT. Firman Alloh dalam Q.S. AlFurqon ayat 48 yang terjemahnya :" Dia-lah yang meniupkan angin (sebagai) pembawa kabar gembira dekat sebelum kedatangan Rahmat-Nya (hujan) dan kami turunkan dari langit air yang amat bersih".

Ayat-ayat dalam rangkaian surat Al-Furqon, Asy-Syuaro dan An-Naml adalah ayat-ayat dakwah para nabi yang di

\footnotetext{
${ }^{4}$ Moh Ali Azis, Ilmu Dakwah, Kencana: Jakarta, 2009, 144.
} 
dalamnya terdapat pula hal-hal yang berkenaan dengan media dakwah. Ini menjadi landasan teologis yang sangat ilmiah untuk mengklaim, menggugat atau meluruskan bahwa seharusnya media komunikasi yang berkembang saat ini terjadi karena keberadaan angin atau sebutlah gelombang elektromagnetik yang dapat nenghantarkan resonansi suara dari suatu tempat ketempat yang lain. Al-Qur'an menyatakan bahwa para nabi bertugas menyampaikan berita gembira dan peringatan kepada manusia. Untuk menyebarluaskan pesan ilahiyah itu. Allah menciptakan angin sebaga fasilitas atau media dakwah sebagaimana Nabi Suaiman yang dapat menangkap resonansi berbagai suara binatang dan ketundukan angin kepadanya dengan ijin Alloh. ${ }^{5}$

Di dalam Q.S. An-Naml ayat 15 sampai dengan 44, Allah memberi pelajaran pada umat Islam dengan kisah Sulaiman yang mandakwahkan ajaran tauhid melalui beberapa media. Mulai dengan menggunakan media lisan tulisan (surat) sampai media semacam 3G (dimasa sekarang) atau ICT dan bahkan belum sepadan melampaui itu. Lebih gamblang dalam ayat ke 40 Alloh menginformasikan yang terjemahnya: " Berkatalah seorang yang mempunyai ilmu dari al-kitab, 'Aku akan membawa singgasana itu kepadamu sebelum matamu berkedip' maka tatkala Sulaiman melihat singgasana itu terletak dihadapannya, ia pun berkata: ' Ini termasuk karunia tuhanku untuk mencoba aku bersyukur atau mengingkari (akan nikmatNya). Dan barang siapa bersyukur maka sesungguhnya dia bersyukur untuk (kebaikan) dirinya sendiri dan barang siapa yang ingkar, maka sesungguhnya Tuhan-Ku maha kaya lagi maha Mulia".

Pada masa nabi Sulaiman, Fenomena cyber space pernah muncul dan bahkan keunggulannya dimiliki oleh manusia

${ }^{5}$ Shohib, Tinjauan Teologis dan Teoritis Dakwah Multimedia, Jurnal: Kemenag.go.id. diakses pada tanggal 14 Desember 2015. 
ketimbang Ifrit dengan dapat memindahkan benda materiil dari satu tempat ketempat yang lain. Saat ini kemajuan teknologi informasi dan komunikasi seperti internet pun seolah-olah menjadi benak alias otak luar seluruh manusia dimuka bumi. Tak heran jika sejumlah cendekiawan pelopor internet mengira bahwa sarana komunikasi dan informasi yang tercipta di dalamnya akan mempercepat proses serebralisasi bumi. Sebagai akibatnya, semua manusia akan terdorong menjadi sebuah kesatuan oraganis besar. Kesatuan umat manusia inilah yang diharapkan menjadi terminal spiritualitas paling akhir seperti yang diramalkan di tahun 30-an oleh paleontolog yang juga seorang pastur Ordo Jesuit Prancis, bernama Teilhard de Chardin sebagai titik omega, yaitu titik akhir proses evolusi semesta. Tentu apabila ditarik pada wilayah materialis empiris fenomena itu itu adalah proses evolutif, tetapi dalam pendekatan spiritualitas hal itu adalah suasana revolusi sebagaimana para Sufi yang mukhasafah bersatu dengan jagat raya. ${ }^{6}$

Dengan demikian, angin yang termaktub dalam AlQur'an sebagian adalah gelombang elektromagnetik yang diperuntukan menjadi media dakwah dan komunikasi para nabi untuk menyebarkan ajaran Islam. Fondasi teologis ini diadopsi oleh orang-orang non muslim yang menemukan dan mengembangkan multimedia berbasis teknonologi informasi dan komunikasi dengan mengekplorasi manfaat gelombang elektromagnetik untuk kemajuan ilmu pengetahuan dan teknologi. Tentunya, tanpa harus mengklaim dan menemukan kembali, realitas sudah membuktikan bahwa kemajuan teknologi informasi dan komunikasi itu sejalan dan bahkan ruhnya sudah diinformasikan Allah di dalam Al-Qur'an.

Perkembangan teknologi informasi dan komunikasi dalam bentuk pemanpaatan partikel bermuatan listrik (elektron) kini banyak berbentuk produk yang beragam bentuk sesuai

\footnotetext{
${ }^{6}$ Ibid.
} 
dengan fungsinya masing-masing seperti telephon kabel dan selular, radio, televisi , internet dan lain-lain. Biolog Gregory Stock, berpendapat bahwa masyarakat teknologi kontemporer sedang mengalami metamorfosis menjadi suatu yang disebut MetaMan yaitu suatu superorganisme yang kemampuannya melebihi kemampuan manusia secara individu. Akan tetapi, menurut Heylighen, MetaMan itu tidak akan lahir begitu saja. Itulah sebabnya dia bersama rekannya John Bollen, Bereksperimen dengan program-program internet yang dapat menjadikan World Wide Web lebih cerdas dengan membuat link-linknya lebih adaktip seperti halnya urat-urat penghubung antar sel saraf dalam otak manusia. ${ }^{7}$

\section{Dakwah Dalam Dunia Cybermedia (Sosial Network).}

Perkembangan teknologi saat tidak dapat dibantah lagi. Dunia digital sekarang seolah sudah menjadi tren masyarakat terkini. Meskipun teknologi digital sangat membantu dan meringankan para pemakainya (user) akan tetapi teknologi manual masih dibutuhkan dan tidak untuk ditinggalkan secara total.

Banyak media yang digunakan untuk sarana berdakwah seperti: Televisi, Radio, Koran, Majalah dan sekarang yang sedang populer adalah Internet. Dengan perkembangan internet yang cukup pesat di Indonesia memang banyak keuntungan yang bisa dimanfaatkan, salah satunya adalah kemudahan dalam berdakwah.

Banyak hal yang akan kita dapatkan dengan berdakwah melalui internet. Tentunya kita tidak bisa dengan bebas dan keras menyuarakan pendapat kita, ada etika dan peraturan tersendiri meskipun di dunia maya. Dan ini sejalan dengan prinsip dakwah Islamiyah, bahwa dalam berdakwah harus selalu dengan lemah lembut dan memilih kata yang baik (qoulul

\footnotetext{
${ }^{7}$ Ibid.
} 
hasan), bukan dengan mendeskreditkan pendapat kelompok lain, apa lagi menggunakan kata-kata kasar. Esensinya berdakwah tidak hanya sekedar berorasi atau hanya berkata-kata saja, tetapi berdakwah dengan memberikan uswah khasanah.

Secara garis besar metodologi dakwah yang digunakan pada media internet tetap berpedoman pada al-Qur'an surat Annahl ayat 125 yang artinya sebagai berikut: "Serulah (manusia) kepada jalan Tuhan-mu dengan hikmah dan pelajaran yang baik dan bantahlah mereka dengan cara yang baik. Sesungguhnya Tuhanmu Dialah yang lebih mengetahui tentang siapa yang tersesat dari jalan-Nya dan Dialah yang lebih mengetahui orang-orang yang mendapat petunjuk."

Berdakwah melalui media internet termasuk cukup mudah dan sangat praktis bila dibandingkan dengan dakwah secara langsung. Tidak hanya jangkauannya yang sangat luas, internet juga menghilangkan batas-batas rasisme, golongan, agama dan lainnya sehingga internet menjadi media bebas untuk menuangkan pemikiran seseorang dalam sebuah tulisan dan tidak terbatas oleh waktu. Di samping itu, materi pembahasan yang ditulis dengan teliti dan disampaikan secara tidak langsung (tidak melalui ceramah) akan lebih detail dan dapat ditelaah pembacanya secara berulang-ulang kapanpun dan dimanapun ia berada. Sebagai contoh, untuk menjelaskan satu fenomena di masyarakat, seorang da'I (penulis) bisa memasukkan data-data pendukung di dalam tulisannya. Jika terjadi kesalahan diksi kata dan atau referensi yang kurang jelas, penulis dapat memperbaikinya sebelum benar-benar dishare ke internet. Demikian pula dengan pembacanya, jika pembaca (mad'u) belum dapat memahami permasalahan yang dibahas, ia dapat membaca kembali teks secara berulang-ulang.

Internet menjadi salah satu media paling efektif untuk menyalurkan bakat atau gagasan. Hal ini disebabkan oleh jangkauan internet yang dapat diakses secara global oleh seluruh 
manusia di seluruh penjuru dunia. Meskipun demikian, seseorang juga harus dapat bijak dalam menggunakan teknologi ini karena internet bagaikan dua belah mata pisau yang dapat membentuk manusia-manusia berkepribadian positif dan juga sebaliknya apabila seseorang tidak bijak dalam menggunakannya maka dapat membentuk manusia-manusia berkepribadian negatif.

Dalam konteks dakwah Islam tentunya segala bentuk kemajuan teknologi informasi itu adalah bagian dari karunia Allah yang wajib disyukuri dengan cara dipelajari dan dipergunakan untuk kemajuan dan kemaslahatan umat. Bukan sebaliknya, anti pati terhadap multimedia komunikasi dan informasi. Sehingga media Informasi dan komunikasi itu malah dikuasai dan digunakan oleh sekelompok orang yang berorientasi pada kesenangan hidup dan kesenangan hawa nafsu dengan dorongan materialisme, kapitalisme, hedonisme dan seterusnya. Sebagai contoh, kemajuan tekhnologi informasi dan komunikasi dipergunakan untuk meng-upload konten-konten yang berbau pornografi. Tentunya ini akan jauh lebih bermanfaat jika ketidak-terbatasan ruang dan waktu dalam intenet dipergunakan untuk menyebarluaskan ajaran dan nilainilai keIslaman. Oleh karena itu, dakwah melalui multimedia berbasis teknologi informasi dan komunikasi menjadi kebutuhan mutlak yang tidak bisa ditawar lagi. Sudah saatnya para pegiat dakwah mengejar ketertinggalannya dalam konteks pemanfaatan teknologi informasi dan komunikasi untuk berdakwah dengan standar minimal menjadi pengguna (user).

\section{Dinamika Komunikasi Islam di Media Online}

Sesungguhnya menyampaikan dakwah Islam adalah kewajiban bagi setiap Muslim. Sebagaimana sabda Nabi Muhammad SAW "Sampaikanlah dariku walau satu ayat". Manusia dalam kerugian kecuali orang yang saling nasehat- 
menasehati dengan kebenaran dan kesabaran, begitu firman Allah dalam surat Al 'Ashr. Selain itu, dalam Al-Quran disebutkan bahwa salah satu ciri umat terbaik dalam pandangan Allah adalah kaum mukminin yang selalu melakukan jihad dakwah ini. Dakwah tidak hanya dilakukan melalui satu pendekatan saja, melainkan perlu dilakukan dengan berbagai pendekatan, termasuk pemanfaatan teknologi internet.

Berkaitan dengan dakwah di dunia maya, Islam sebagai agama yang responsif terhadap segala perubahan dan keadaan, sudah selayaknya melakukan evaluasi terhadap "dakwah konvensional" yang dilakukan selama ini. Dakwah dalam arti yang luas (bukan sekedar tabligh atau ceramah) dituntut untuk mampu menembus dunia cyber dalam rangka menebarkan benih- benih Al Islam. Amar Ahmad dalam jurnal Ilmu Komunikasi menjelaskan lima alasan mengapa dakwah dipandang penting untuk dihadirkan di dunia maya ${ }^{8}$, diantaranya:

\section{Setiap orang berhak untuk menerima dakwah.}

Dakwah bukanlah terbatas hanya untuk sebagian kalangan dan melupakan kalangan yang lain. Bahkan Rasulullah Muhammad SAW mengajarkan para sahabatnya dan juga kita umatnya untuk berdakwah bukan hanya ditujukan kepada sesama muslim, tapi juga harus menyentuh sisi-sisi di luar kaum muslimin. Oleh sebab itu upaya untuk berdakwah kepada para pengguna internet dipandang penting untuk dilakukan.

Dari beberapa referensi yang ada, tidak sedikit pengguna internet yang awalnya nonmuslim menjadi tertarik kepada Islam. Bahkan dari sekian banyak yang tertarik itu, di antaranya telah berhasil menemukan kesucian dan kebenaran Islam melebihi orang-orang yang lebih dahulu memeluk Islam. Ini

\footnotetext{
${ }^{8}$ Amar Ahmad, Dinamika Komunikasi Islami di Media Online, Jurnal Ilmu Komunikasi, Volume 11, Nomor 1, Januari- April 2013. 
menjadi bukti otentik tentang dampak positif dakwah yang dilakukan di internet.

\section{Dakwah Dilakukan untuk Mengenalkan Ajaran Islam}

Sebuah proses pengenalan terhadap Islam mutlak diperlukan dalam rangka menyebarkan agama Islam. Pengenalan ini sangat penting, karena akan menentukan apakah pemahaman seseorang terhadap Islam sudah baik dan benar. Hal ini sesuai dengan firman Allah dalam surat Al An'am ayat 153: "Dan bahwa (yang Kami perintahkan) ini adalah jalan-Ku yang lurus, maka ikutilah dia dan janganlah kamu mengikuti jalan- jalan (yang lain), karena jalan-jalan itu menceraiberaikan kamu dari jalan-Nya, yang demikian itu diperintahkan Allah kepada kamu agar kamu bertaqwa”.

Dakwah dapat diibaratkan sebagai pengenalan sebuah produk kepada seseorang. Keberhasilan menarik audiens tergantung pada bagaimana dan pendekatan apa yang digunakan untuk memperkenalkan produk. Pengenalan Islam melalui dakwah menjadi sangat urgen di internet. Hal ini didasari pada fakta bahwa saat ini manusia yang menjalani "kehidupan" dalam dunia maya sudah mencapai angka puluhan juta.

\section{Dakwah Memiliki Arti yang Sangat Luas.}

Pemahamna umum di masyarakat saat banyak yang mendefinikan dakwah hanya sebatas pada acara-acara tabligh ataupunceramah-ceramah yang dilakukan oleh mubaligh di atas podium. Padahal segala upaya yang ditujukan untuk menyeru dan mendekatkan diri ke kepada Allah adalah termasuk dalam kategori dakwah. Sementara itu, dakwah merupakan manifestasi ibadah seseorang hamba terhadap tuhannya jika dilakukan dengan niat karena Allah dan dengan syariat yang benar. Sehingga dengan demikian menyebarkan Islam melalui media internet juga adalah sebuah dakwah sekaligus bernilai ibadah di hadapan Allah SWT. 
4. Setiap Muslim Wajib Mencegah Kemungkaran.

Kelebihan cyber yang memberikan kebebasan kepada masyarakat untuk berpikir dan mengakses segala hal kapanpun dan dimanapun, ternyata di satu sisi justru memberikan dampak negatif kepada msayarakat. Belum ditemukannya mekanisme yang tepat untuk membatasi kebebasan tanpa batas yang dimaksud semakin memperkeruh keadaan. Sehingga jadilah internet sebagai lahan subur bagi tumbuhnya kemaksiatankemaksiatan seperti pornografi dan perjudian yang dilakukan secara online. Melihat realitas yang seperti itu, kehadiran $\mathrm{Al}$ Haq sebagai antitesa sejati Al Bathil di dunia maya adalah sebuah keharusan yang tidak bisa ditawar-tawar lagi. Sebagaimana Allah SWT berfirman dalam surat Ali Imran ayat 110 yang memerintahkan kita untuk selalu tolong menolong dalam hal kebaikan dan mencegah kemungkaran-kemungkaran. Kalian adalah umat terbaik yang dilahirkan untuk manuasia, menyuruh kepada yang ma'ruf dan mencegah dari yang mengkar dan beriman kepada Allah. Sekiranya ahli kitab beriman, tentulah itu lebih baik bagi mereka; di antara mereka ada yang beriman dan kebanyakan mereka dalah orang-orang yang fasik. (QS. Ali Imran: 110). ${ }^{9}$

5. Dakwah Cyber Akan Meningkatkan Profesionalisme Para Aktivis Dakwah

Sebuah kebenaran yang tidak tertata dengan baik akan dikalahkan oleh kebathilan yang tertata dengan baik. Itulah pesan yang disampaikan oleh Sahabat Rasul yang mulia Ali bin Abi Thalib ra, yang bila kita mencoba memahaminya lebih jauh sebuah dakwah yang tidak dilakukan secara professional akan ditumbangkan oleh kemaksiatan yang dikerjakan dengan penuh profesionalisme. Berkaitan dengan pembentukan sikap ihsan tersebut, maka profesionalisme aktivis dakwah akan terus terpupuk melalui dakwah cyber seiring dengan teknologi yang

\footnotetext{
${ }^{9}$ Al-Qur'an: 3, 110.
}

Volume 26 Nomor 1 Januari 2015 
akan terus berkembang. ${ }^{10}$

\section{Keunggulan Internet sebagai Media Dakwah}

Internet memiliki beberapa kelebihan bila dibandingkan dengan media yang lain. Sebagaimana Pardianto merinci bebrapa keistimewaan internet yang dapat memudahkan proses dakwah ${ }^{11}$, di antaranya:

1. Tidak terhalang oleh ruang dan waktu.

Sebagaimana yang telah penulis jelaskan pada sub bab sebelumnya bahwa dakwah melalui internet dapat diakses di mana saja, oleh siapa saja dan kapan saja mereka menginkannya. Oleh karena itu sebelum menulis pesan dakwah di dunia maya, setiap $d a^{\prime} i$ harus memahami ilmu-ilmu yang bersumber dari al-Qur'an, Hadist, Ijma dan Qiyas. Ketidakpahaman terhadap ilmu-ilmu agama itu bisa jadi berbahaya dan menyesatkan ma'u dalam hal ini pengguna internet.

2. Dakwah menjadi lebih variatif.

Selama ini kita sering mengartikan bahwa aktifitas dakwah hanya sebatas bil lisan di atas panggung. Kehadiran cyber memberikan banyak cara bagi kita untuk menyampaikan pesan-pesan dakwah. Selain tulisan, kita dapat membuat materi dakwah dalam bentuk gambar, audio, e-book (buku elektronik) ataupun video sehingga objek dakwah dapat memilih bentuk media yang disukai.

3. Jumlah pengguna internet semakin meningkat.

Pertumbuhan pengguna internet yang selalu meningkat merupakan kabar baik bagi para da'i yang akan berdakwah di dunia maya, karena objek dakwah pun semakin meningkat tajam.

${ }^{10}$ Amar Ahmad, Dinamika Komunikasi Islami di Media Online.

11 Pardianto, Meneguhkan Dakwah Melalui New Media, Jurnal: Komunikasi Islam, ISBN 2088-6314, Volume 03, Nomor 01, Juni 2013. 216

Volume 26 Nomor 1 Januari 2015 
4. Hemat biaya dan energi.

Dengan menyajikan materi dakwah di internet, objek dakwah tidak perlu datang ke narasumber dan membeli buku untuk menjawab masalah yang dihadapi. Sehingga bisa membantu saudara kita agar tidak mengeluarkan biaya dan tenaga ekstra guna memperoleh informasi syar'i yang mereka cari.

Dengan demikian strategi yang dilakukan dalam kegiatan membangun jaringan dakwah adalah dengan memanfaatkan perkembangan global connection. Sistem ini merupakan salah satu alternatif untuk dijadikan sebagai wasilah untuk berdakwah. Aspek keuntungan yang diperoleh dengan pemanfaatan jaringan internet ini antara lain dapat mempererat jalinan persaudaraan antara satu dengan lainnya juga dapat memberikan informasi dalam waktu yang singkat (aspek sosial), dapat berdiskusi mengenai perkembangan Islam (aspek agama) serta pengembangan Ilmu Pengetahuan Teknologi.

\section{Kesimpulan}

Teknologi informasi dan komunikasi adalah produk media komunikasi yang dikembangkan dalam upaya memungsikan komunikasi itu untuk menginformasikan (to Inform), untuk mendidik (to educate), untuk menghibur (to entertain) dan untuk mempengaruhi (to influence). Perkembangan tekhnologi komunikasi semakin pesat dan tidak dapat dihindarkan lagi. Kehadiran cybermedia (Social Network) memudahkan setiap orang untuk mengakses segala informsai yang di butuhkan di manapun dan kapanpu. Tetapi di sisi lain, cybermedia juga memberikan dampak negatif bagi mereka yang tidak dapat memanfaatkannya.

Dalam konteks dakwah Islam tentunya segala bentuk kemajuan teknologi informasi itu adalah bagian dari karunia Allah yang wajib disyukuri dengan cara dipelajari dan dipergunakan untuk kemajuan dan kemaslahatan umat. Bukan 
sebaliknya, anti pati terhadap multimedia komunikasi dan informasi. Sehingga media Informasi dan komunikasi itu malah dikuasai dan digunakan oleh sekelompok orang yang berorientasi pada kesenangan hidup dunia dan hawa nafsu dengan dorongan materialisme dan kapitalisme. Tentunya akan jauh lebih bermanfaat jika ketidak-terbatasan ruang dan waktu dalam cybermedia dipergunakan untuk menyebarluaskan ajaran dan nilai-nilai keIslaman. Oleh karena itu, dakwah melalui multimedia berbasis teknologi informasi dan komunikasi menjadi kebutuhan mutlak. Sudah saatnya para pegiat dakwah mengejar ketertinggalannya dalam konteks pemanfaatan teknologi informasi dan komunikasi untuk berdakwah dengan standar minimal menjadi pengguna (user). 


\section{DAFTAR PUSTAKA}

Azis, Moh. Ali. Ilmu Dakwah. Kencana: Jakarta, 2009.

Ahmad, Amar. Dinamika Komunikasi Islami di Media Online. Jurnal Ilmu Komunikasi. Volume 11. Nomor 1. JanuariApril 2013.

Arbi, Armawati. Dakwah dan komunikasi. UIN Jakarta Press: Jakarta, 2003.

As Shouwy, Ahmad. Metode Dakwah dalam Perkembangan IPTEK. Gema Insan Press: Jakarta, 1985.

Abd. Khaliq, Abdurahman. Strategi Dakwah Dalam Menghadapi Perkembangan Teknologi. CV. Pustaka Mantik: Jakarta, 2002.

Syukir. Asmuni Dasar-dasar Strategi Dakwah Islam. Al Ikhlas: Surabaya, 1983.

Pardianto. Meneguhkan Dakwah Melalui New Media. Jurnal: Komunikasi Islam. ISBN 2088-6314. Volume 03. Nomor 01. Juni 2013.

Shohib. Tinjauan Teologis dan Teoritis Dakwah Multimedia. Jurnal: Kemenag.go.id. diakses pada tanggal 14 Desember 2015.

Pardianto. Meneguhkan Dakwah Melalui New Media. Jurnal: Komunikasi Islam. ISBN 2088-6314. Volume 03. Nomor 01. Juni 2013.

Faradillah Iqmar Omar. Penerimaan Media Sosial Sebagai Medium Dakwah dalam Kalangan Mahasiswa Kuis. Eproceedings of the Conference on Management and Muamalah (CoMM 2014), 26-27 May 2014. 